\title{
EKSISTENSI MAWAH (BAGI HASIL) TANAH PERTANIAN DALAM MASYARAKAT HUKUM ADAT DI KECAMATAN KUTA COT GLIE, KABUPATEN ACEH BESAR
}

\author{
EXISTENCY OF MAWAH (PRODUCT SHARE) OF \\ AGRICULTURAL LAND IN A TRADITIONAL LAW SOCIETY IN \\ KUTA COT GLIE SUB-DISTRICT, ACEH BESAR DISTRICT
}

\author{
Suhaimi \\ Universitas Syiah Kuala, Banda Aceh \\ Corresponding Author: pak_emy@unsyiah.ac.id \\ Abdurrahman \\ Universitas Syiah Kuala, Banda Aceh \\ Email: abdurrahman@unsyiah.ac.id \\ Ishak \\ Universitas Syiah Kuala, Banda Aceh \\ Email: ishak_fh@unsyiah.ac.id
}

\begin{abstract}
The customary law communities in Kuta Cot Glie sub-District of Aceh Besar District have practiced sharing contract for agriculturalland (Mawah) based on Customary Law and do not follow the Law Number 2 of 1960, even though in this law certain sanctions are imposed for those who break the law. This research aims to describe the pattern of Mawah that has been practiced by the communities and analyze the factors that cause Mawah still continue to be practiced and maintained in the communities. The research method used in this study is empirical juridical method. Data collection techniques were carried out through literature and field research. All collected data were analyzed by using qualitative approach. The results of this study indicate that the pattern of Mawah contract is carried out by applying Bulueng Lhee pattern (divided into three parts) with a ratio 1:3 after deducting zakat, namely one part for the Mawah giver and two parts for the Mawah recipient. The factors that cause Mawah still exists in the communities are because Mawah is used as a mean of helping people in the communities, it is also used as a tool for land producing and the exist of land occupation through pawning system in the societies.
\end{abstract}

\section{Keywords: Mawah; Profit Sharing; Customary Law}

\begin{abstract}
Abstrak
Masyarakat hukum adat di Kecamatan Kuta Cot Glie Kabupaten Aceh Besar mempraktekkan perjanjian bagi hasil tanah pertanian (Mawah) sesuai dengan Hukum Adat dan tidak berpedoman pada Undang-Undang No. 2 Tahun 1960, walaupun dalam undang-undang tersebut ada ancaman sanksi bagi yang melanggarnya. Tujuan penelitian ini adalah untuk mendeskripsikan pola Mawah yang dipraktekkan masyarakat dan untuk menganalisis faktor penyebab Mawah masih tetap berlangsung dan masih dipertahankan dalam masyarakat. Metode penelitian yang digunakan adalah metode yuridis empiris. Teknik pengumpulan data dilakukan melalui penelitian kepustakaan dan lapangan. Data yang diperoleh
\end{abstract}


dianalisis dengan menggunakan pendekatan kualitatif. Hasil penelitian menunjukkan bahwa pola perjanjian Mawah dilakukan dengan pola Bulueng Lhee (bagi tiga), dengan perbandingan 1:3 setelah dikurangi zakat, yaitu 1 bagian untuk pemberi Mawah dan 2 bagian untuk penerima Mawah. Faktor penyebab Mawah masih eksis dalam masyarakat karena sebagai sarana tolong menolong antar sesama warga masyarakat, sebagai salah satu cara memproduktifkan tanah dan karena adanya penguasaan tanah secara gadai dalam masyarakat.

\section{Kata Kunci: Mawah; Bagi Hasil; Hukum Adat}

\section{PENDAHULUAN}

Aceh merupakan salah satu Provinsi di Indonesia yang memiliki keistimewaan di bidang penyelenggaraan kehidupan beragama, penyelenggaraan adat, penyelenggaraan pendidikan dan peran ulama dalam setiap penetapan kebijakan daerah. "Keistimewaan ini merupakan bagian dari pengakuan bangsa Indonesia yang diberikan kepada daerah (Aceh) mengingat perjuangan dan nilai-nilai hakiki masyarakat Aceh yang tetap dipelihara secara turun-temurun sebagai landasan spiritual, moral dan kemanusiaan". ${ }^{1}$ Di samping itu, "kehidupan masyarakat Aceh yang religius, telah menempatkan ulama pada peran yang terhormat dalam kehidupan bermasyarakat, berbangsa, dan bernegara serta sangat menjunjung tinggi adat istiadat yang berlaku dalam masyarakat. Kemudian, masyarakat Aceh taat bahkan sangat fanatik terhadap ajaran agamanya (Islam), memberikan gambaran bahwa Islam sudah terbina dan telah mengakar dalam diri masyarakat Aceh. Walaupun tidak semua masyarakat Aceh melaksanakan ajaran Islam yang sejati secara murni, akan tetapi agama Islam sudah turun-temurun sejak dari nenek moyangnya". ${ }^{2}$

Keistimewaan yang diakui dan diberikan kepada Aceh menurut ketentuan Pasal 3 ayat (2) Undang-Undang No. 44 Tahun 1999 tentang Penyelenggaraan Keistimewaan Propinsi Daerah Istimewa Aceh, meliputi :

a. "Keistimewaan dalam penyelenggaraan kehidupan beragama;

b. keistimewaan dalam penyelenggaraan kehidupan adat;

c. keistimewaan dalam penyelenggaraan kehidupan pendidikan; dan

d. keistimewaan dalam hal adanya peran ulama dalam penetapan kebijakan daerah".

Dalam mewujudkan keistimewaan tersebut dalam Pasal 6 Undang-Undang No. 44 Tahun 1999 dinyatakan bahwa "daerah dapat menetapkan berbagai kebijakan dalam upaya pemberdayaan, pelestarian, dan pengembangan adat serta lembaga adat di wilayahnya yang dijiwai dan sesuai dengan syariat Islam”. Kemudian Pasal 7 Undang-

1 Hasan Basri, Kedudukan Syariat Islam di Aceh dalam Sistem Hukum Indonesia. KANUN Jurnal Ilmu Hukum, vol.13 no.3 edisi Desember 2011, hlm. 87.

2 Muhammad Arifin dan Khadijah Binti Mohd Khambali, Islam dan Akulturasi Budaya Lokal di Aceh (Studi Terhadap Ritual Rah Ulei di Kuburan Dalam Masyarakat Pidie Aceh). Jurnal Ilmiah ISLAM FUTURA, vol.15 no.2 edisi Februari 2016, hlm. 259. 
Undang No. 44 Tahun 1999 menyatakan bahwa "daerah dapat membentuk lembaga adat dan mengakui lembaga adat yang sudah ada sesuai dengan kedudukannya masingmasing di Propinsi, Kabupaten/Kota, Kecamatan, Kemukiman, dan Kelurahan/Desa atau Gampong".

Sehubungan dengan hal tersebut di atas, Undang-Undang No. 11 Tahun 2006 tentang Pemerintahan Aceh di dalam Pasal 98 telah dijelaskan bahwa "Lembaga Adat merupakan sarana atau wadah bagi masyarakat untuk berpartisipasi dalam penyelenggaraan Pemerintahan Aceh di bidang ketenteraman, kerukunan, ketertiban dan keamanan masyarakat. Oleh karena itu jika terjadi permasalahan atau perselisihan masalah sosial kemasyarakatan diselesaikan secara adat melalui Lembaga Adat".

Salah satu praktek dalam pengelolaan sumber daya alam dalam masyarakat adat di Aceh secara turun temurun adalah "Mawah atau bagi hasil (bagi hase' atau weuk hase') dan ada juga yang menggunakan istilah Meudualaba, yaitu suatu perjanjian dimana pemilik tanah (terutama tanah pertanian) menyerahkan tanahnya untuk dikelola atau diusahakan oleh orang lain dengan cara membagi hasilnya sesuai akad yang disepakati. Mawah merupakan cara bagi hasil dalam mengerjakan sawah, kebun dengan mempergunakan alat-alat sendiri, dengan memperoleh setengah bagian (sesuai perjanjian atau akad) dari penghasilannya. Berdasarkan pengertian tersebut dapat dipahami bahwa Mawah merupakan kesepakatan antara dua pihak, di mana pihak pertama memberikan lahan pertanian atau perkebunan, kepada pihak kedua untuk digarap maupun dikelola, dan setelah panen hasilnya dibagi dua atau sesuai kesepakatan".3

Mawah telah dipraktekkan oleh masyarakat Aceh sejak Abad XVI yang lalu, bahkan terus berlangsung dan masih tetap eksis hingga saat sekarang ini. "Populernya Mawah di Aceh tidak terlepas dari budaya masyarakat Indonesia pada umumnya yang saling bantu membantu atau tolong menolong, juga khususnya masyarakat Aceh yang memang budaya tolong-menolong dan bantu membantu sudah 'mendarah daging' di tengah-tengah masyarakat. Hal ini dikarenakan masyarakat Aceh sangat taat pada ajaran agamanya (Islam), bahkan masyarakatnya sangat fanatik terhadap agama Islam. Keadaan ini memberikan gambaran bahwa Islam sudah terbina dan telah mengakar serta menyatu dalam diri masyarakat Aceh, apalagi umat Islam dianjurkan untuk saling tolong menolong". 4

Mengenai Mawah (bagi hasil tanah pertanian) juga telah diatur di dalam UndangUndang No. 2 Tahun 1960 Tentang Perjanjian Bagi Hasil. Akan tetapi Mawah yang

\footnotetext{
3 Syamsuddin, Peran Konsep "Mawah” Sebagai Edukasi Permodalan Masyarakat Aceh. Jurnal NEGOTIUM, vol.1 no.1 edisi April 2018, hlm. 43.

4 Azhari, https://aceh.kemenag.go.id/berita/510267/azhari-tingkatkan-kepedulian-sosial-untuk-membantu-sesama-di-tengah-wabah, diakses pada tanggal 02 Agustus 2020.
} 
dipraktekkan oleh masyarakat Kecamatan Kuta Cot Glie Kabupaten Aceh Besar didasarkan pada Hukum Adat yang tentunya berbeda dengan bagi hasil yang diatur dalam Undang-Undang No. 2 Tahun 1960. Menurut ketentuan Pasal 3 Undang-Undang No. 2 Tahun 1960 ditegaskan bahwa : "Semua perjanjian bagi hasil harus dibuat secara tertulis oleh pemilik tanah dan penggarap di hadapan Kepala Desa tempat letak tanah tersebut berada dan disaksikan oleh masing-masing 2 (dua) orang saksi dari kedua belah pihak, yang kemudian disahkan oleh Camat (Kepala Kecamatan) setempat. Peraturanperaturan yang diperlukan untuk melaksanakan perjanjian bagi hasil ditetapkan oleh Menteri Muda Agraria".

Selanjutnya dalam Pasal 4 Undang-Undang No. 2 Tahun 1960 ditegaskan bahwa "perjanjian bagi-hasil diadakan untuk jangka waktu sekurang-kurangnya 3 (tiga) tahun bagi tanah sawah dan sekurang- kurangnya 5 (lima) tahun bagi tanah kering. Jika pada saat berakhirnya jangka waktu perjanjian bagi hasil di atas tanah tersebut masih terdapat tanaman yang belum dapat dipanen, maka perjanjian bagi hasilnya terus berjalan sampai waktu tanaman itu selesai dipanen, tetapi perpanjangan waktu itu tidak boleh lebih dari 1 (satu) tahun".

Namun demikian praktek bagi hasil tanah pertanian (Mawah) dalam masyarakat Aceh, khususnya masyarakat Kecamatan Kuta Cot Glie Kabupaten Aceh Besar tidak mendasarkan diri pada Undang-Undang No. 2 Tahun 1960, walaupun pelanggaran terhadap ketentuan tersebut dapat diancam dengan sanksi pidana berupa denda. Dalam arti bahwa masyarakat tidak mengindahkan ketentuan yang mengharuskan perjanjian bagi hasil dibuat secara tertulis di hadapan Kepala Desa dengan jangka waktunya sekurang-kurangnya 3 (tiga) tahun bagi tanah sawah dan 5 (lima) tahun bagi tanah kering. Mawah dilaksanakan secara turun temurun dan tetap eksis hingga sekarang ini yang didasarkan pada hukum adat.

Praktek Mawah dilaksanakan menurut hukum adat dan tidak didasarkan pada Undang-Undang No. 2 Tahun 1960, menurut Asnawi Zainun (Ketua Majelis Adat Aceh Kabupaten Aceh Besar) karena aturan tentang Mawah sudah diwariskan secara turun temurun dalam kehidupan masyarakat. Praktek Mawah dalam masyarakat Aceh pola (skema) bagi hasilnya yang disebut dengan istilah Buluenglebih adil dan lebih berimbang, karena tidak terlalu terikat atau terpaku pada perjanjian yang disepakati. Kata Bulueng ditemukan dalam Hadih Maja (ungkapan): 'banja ubee jiplueng, bulueng ubee teuka' (maksudnya: panjang suatu deretan tergantung pada sejauhmana deretan itu sampai, jumlah bagian dari masing-masing pihak tergantung pada berapa yang diperoleh). Hal ini dipengaruhi oleh tingkat kesuburan tanah, ketersediaan irigasi, jarak lahan dengan perkampungan, dan resiko serangan hama. Di samping itu juga Mawah pada lahan yang mati (umoung rhoh), untuk satu atau dua kali panen hasilnya diserahkan seluruhnya 
kepada penggarap. Sehingga aturan dalam hukum adat mengenai Mawah masih menjadi rujukan penting bagi masyarakat dan cenderung mengenyampingkan aturan hukum positif yaitu Undang-Undang No. 2 Tahun 1960." 5

Beberapa penelitian tentang Mawah yang sudah pernah dilakukan, antara lain: Mukhtasar dan Angga Syahputra, dengan judulnya "Optimizing The Mawah Concept for The Economy of The Aceh Community", yang mengkaji "penerapan konsep Mawah dalam bentuk yang lebih luas, dapat mendukung perekonomian Aceh ke arah yang lebih baik. Konsep ini mengutamakan prinsip ekonomi Islam yaitu keikhlasan, ukhuwah, kerja dan produktivitas. Jika dikembangkan, produktivitas kerjanya akan mencapai tiga tujuan, memenuhi kebutuhan hidup (isyba'), mencapai keuntungan yang wajar (irbah), dan menciptakan kesejahteraan secara sosial, terutama pemberdayaan mereka yang tidak mampu dan alam (al-i'mar)". ${ }^{6}$

Kemudian penelitian yang dilakukan oleh Furqan dan Elva Hidayan S, yang berjudul "Pemberdayaan Masyarakat Melalui Tradisi Mawah (Studi Kasus Pemeliharaan Ternak Sapi di Desa Mibo Kecamatan Banda Raya Banda Aceh)". Penelitian ini mengkaji tentang ternak sapi yang dapat membantu masyarakat kurang mampu menjadi terberdaya (berkemampuan) dengan cara Mawah, sehingga tradisi Mawah ini mampu mensejahterakan masyarakat".7

Selanjutnya Syamsuddin yang penelitiannya berjudul "Peran Konsep Mawah Sebagai Edukasi Permodalan Masyarakat Aceh", mengkaji tentang "konsep mawah yang dapat menjadi sebuah konsep permodalan kepada masyarakat yang diimplementasikan oleh masyarakat Aceh. Sehingga konsep Mawah dapat menjadi sebagai edukasi mekanisme permodalan bagi masyarakat".

Selain penelitian di atas, ditemukan juga 3 (tiga) penelitian lain, yaitu: (1) T. Hafid Mushawwir (2013) dengan judulnya "Sistem Mawah Pada Usaha Ternak Sapi Dan Kontribusinya Terhadap Pendapatan Keluarga Di Kecamatan Blang Bintang Kabupaten Aceh Besar", (2) Cut Miftahul Jannah (2017) dengan judulnya "Pelaksanaan Perjanjian Bagi Hasil (Mawah) Ternak Sapi Dalam Masyarakat Adat (Suatu Penelitian Di Kecamatan Indrajaya Kabupaten Pidie)", dan (3) Azar Rauzi (2017) dengan judulnya "Pola Mawah Sapi Di Kemukiman Lampanah Leungah Kecamatan Seulimeum Kabupaten Aceh Besar". Ketiga penelitian tersebut berkaitan dengan sistem bagi hasil Mawah Ternak

5 Wawancara dengan Narasumber Asnawi Zainun, Ketua Majelis Adat Aceh (MAA) Kabupaten Aceh Besar, Jumat, 5 Maret 2021.

6 Mukhtasar dan Angga Syahputra, Optimizing The Mawah Concept for The Economy of The Aceh Community. IQTISHODUNA: Jurnal Ekonomi Islam, vol.9 no.2 edisi Oktober 2020, hlm. 173.

$7 \quad$ Furqan dan Elva Hidayan S., Pemberdayaan Masyarakat Melalui Tradisi Mawah (Studi Kasus Pemeliharaan Ternak Sapi di Desa Mibo Kecamatan Banda Raya Banda Aceh). AL-IDARAH: Jurnal Manajemen dan Administrasi Islam, vol.2 no. 1 edisi Juni 2018, hlm. 25.

8 Syamsuddin, Op. Cit., hlm. 42. 
Sapi, sedangkan penelitian ini lebih difokuskan pada eksistensi dari lembaga Mawah itu sendiri, khususnya Mawah tanah pertanian.

Dengan demikian penelitian ini berbeda dengan penelitian-penelitian sebelumnya. Adapun tujuan penelitiannya adalah untuk mendeskripsikan pola bagi hasil tanah pertanian (Mawah) dan menganalisis faktor penyebab bagi hasil tanah pertanian (Mawah) masih tetap berlangsung dan masih dipertahankan dalam masyarakat.

Jenis penelitian ini termasuk dalam "penelitian yuridis sosiologis/empiris/non doktrinal dengan pendekatan kualitatif, dengan mempertimbangkan data yang dihasilkan berupa kata-kata dan bukan berupa kuantitas dari angka-angka". Penelitian ini dilaksanakan di wilayah Kecamatan Kuta Cot Glie Kabupaten Aceh Besar. Oleh karena populasinya tidak tercatat dan tidak terdata, baik di Kantor Keuchik (Kepala Kampung/Kepala Desa) maupun di Kantor Camat, maka pengambilan sampel dilakukan secara purposif (Purposive Sampling). Dalam hal ini pemilihan responden ditentukan berdasarkan pertimbangan peneliti. Data primer berupa data lapangan diperoleh melalui wawancara dengan para responden, antara lain para pihak dalam perjanjian Mawah (pemberi Mawah dan penerima Mawah). Di samping itu juga dengan mewawancarai para informan, seperti tokoh masyarakat dan Imam Masjid Gampong (Kampung). Data sekunder diperoleh melalui buku-buku, jurnal ilmu hukum dan ilmu sosial lainnya serta peraturan perundang-undangan yang berlaku yang ada kaitannya dengan penelitian ini. Data yang diperoleh, baik data primer maupun data sekunder dianalisis secara kualitatif dan disajikan secara deskriptif.

\section{PEMBAHASAN}

\section{Pola Bagi Hasil Tanah Pertanian (Mawah) Dalam Masyarakat Kecamatan Kuta Cot Glie Kabupaten Aceh Besar}

Sebagaimana telah dikemukakan sebelumnya bahwa praktek Mawah sudah menjadi tren dalam masyarakat Aceh sejak beberapa abad yang lalu hingga saat sekarang ini. "Mawah yang sangat populer dalam masyarakat Aceh merupakan salah satu modal sosial yang masih bertahan hingga sekarang ini dan sudah berlangsung sejak abad XVI di era kesultanan Aceh". ${ }^{10}$ Demikian juga halnya dalam kehidupan masyarakat hukum adat di Kecamatan Kuta Cot Glie Kabupaten Aceh Besar, yang hingga saat ini masih berlangsung, karena erat kaitannya dengan semangat tolong menolong sebagai salah satu ajaran dalam Agama Islam.

\footnotetext{
$9 \quad$ Purwaning Rahayu Sisworini, Abdul Majid dan Herman Suryokumoro, Penerapan Honorarium PPAT Sebagai Upaya Untuk Penyetaraan Pelayanan (Studi Kasus Di Kota Malang). Jurnal IUS Kajian Hukum dan Keadilan, vol.8 no.3 edisi Desember 2020, hlm. 517.

10 Syamsuddin, Loc. Cit.
} 
Sistem mawah dalam masyarakat Aceh sering dipraktekkan pada bidang pertanian (seperti ladang, sawah dan kebun) dan bidang peternakan (seperti sapi, kerbau, kambing, dan unggas). Akan tetapi dalam penelitian ini dititik-beratkan pada Mawah tanah pertanian. "Mengenai dengan besaran hasil yang akan dibagikan nantinya sangat tergantung pada kesepakatan (akad) antara pemberi Mawah (pemilik tanah) dengan penerima Mawah (pengelola atau yang mengusahakan tanah tersebut). Namun, tidak selamanya pemberi Mawah merupakan pemilik tanah. Dalam praktek di Kecamatan Kuta Cot Glie Kabupaten Aceh Besar ditemukan pemberi Mawah bukan hanya pemilik tanah, akan tetapi adakalanya juga sebagai pemegang gadai atas tanah pertanian". ${ }^{11}$

Terjadinya Mawah dimulai dari "adanya perjanjian antara pemberi Mawah dengan penerima Mawah untuk mengusahakan atau mengolah tanah, dengan perjanjian hasilnya akan dibagi antara pemberi Mawah dengan penerima Mawah. Perjanjian tersebut dapat berupa pola (skema) perjanjian Mawah-nya, yang dalam masyarakat Kecamatan Kuta Cot Glie Kabupaten Aceh Besar disebut dengan istilah Bulueng"12 dan dapat juga mengenai jangka waktu Mawah. Pola pembagian hasil biasanya mengikuti pola yang berlaku menurut Hukum Adat setempat.

Berdasarkan hasil penelitian diketahui bahwa "pola pembagian hasil dalam perjanjian Mawah di Kecamatan Kuta Cot Glie Kabupaten Aceh Besar dilakukan dengan pola Bulueng Lhee (bagi tiga), yaitu hasilnya dibagi tiga bagian dengan perbandingan $1: 3$ setelah dikurangi zakat (apabila hasilnya sampai Nisab yaitu memenuhi syarat untuk dikenakan zakat )". ${ }^{13}$ Dalam hal ini "zakat hasil pertanian, yang wajib dikeluarkan zakatnya apabila hasilnya mencapai minimal 5 wasaq atau $653 \mathrm{~kg}$ ( 1 wasaq $=60$ sha', sedangkan 1 sha' = 2,176 kg, maka 5 wasaq adalah $5 \times 60 \times 2,176=652,8 \mathrm{~kg}){ }^{\prime},{ }^{14}$ dengan "besaran zakatnya sebesar $10 \%$ apabila sawah tadah hujan atau jenis pengairan lain yang tidak perlu membeli air. Apabila membeli air maka zakatnya sebesar $5 \%$ dari seluruh hasil panen". ${ }^{15}$

Perbandingan 1: 3 dapat dijelaskan bahwa hasil panennya setelah dikeluarkan zakat dibagi dalam 3 bagian, yaitu 1 bagian untuk pemberi Mawah dan 2 bagian untuk penerima Mawah. Namun demikian perbandingan $1: 3$ tersebut masih bersifat fleksibel, dalam arti bahwa "kalau hasil panennya sedikit karena padinya diserang hama (penyakit) atau kemarau, maka pemberi Mawah meminta sedikit saja bagiannya dan tidak mencapai

\footnotetext{
11 Wawancara dengan Narasumber Nurdin, Tokoh Masyarakat Gampong (Kampung) Lam Leuot Kecamatan Kuta Cot Glie Kabupaten Aceh Besar, Sabtu, 27 Juni 2020.

12 Wawancara dengan Narasumber Tgk. Assa'at, Imam Masjid Gampong (Kampung) Krueeng Blang Kecamatan Kuta Cot Glie Kabupaten Aceh Besar, Jumat, 3 Juli 2020.

13 Wawancara dengan Narasumber Ilyas, Tokoh Masyarakat Gampong (Kampung) Krueueng Krueng Kecamatan Kuta Cot Glie Kabupaten Aceh Besar, Sabtu, 4 Juli 2020.

14 Badan Amil Zakat Nasional, Provinsi Kepulauan Bangka Belitung, Zakat Pertanian, https://baznasbabel.com/ zakat-pertanian/, diakses pada tanggal 08 Agustus 2020.

15 Dompet Dhuafa, Cara Menentukan Zakat Hasil Pertanian, Buah-buahan, Bunga dan Sayuran, https://zakat.or.id/ cara-menentukan-zakat-hasil-pertanian/, diakses pada tanggal 08 Agustus 2020.
} 
1 bagian. Hal ini karena pemberi Mawah merasa kasihan terhadap penerima Mawah yang hasil panennya lebih sedikit dibandingkan dengan biasanya". ${ }^{16}$ Begitu juga "jika hasil panennya berlimpah atau lebih banyak dari biasanya, maka setelah menerima bagiannya ( 1 bagian untuk pemberi Mawah dan 2 bagian untuk penerima Mawah), pemberi Mawah akan memberikan bonus kepada penerima Mawah karena penerima Mawah telah bekerja dengan tekun sehingga memperoleh hasil yang maksimal". ${ }^{17}$

Pola pembagian hasil dalam Mawah yang bersifat fleksibel tersebut merupakan salah satu bentuk solidaritas yang menjadi ikatan sosial di antara sesama warga masyarakat, sehingga tidak menimbulkan rasa kecemburuan sosial di kalangan penerima Mawah terhadap pemberi Mawah. "Solidaritas ini merupakan salah satu nilai luhur bangsa Indonesia yang sudah menjadi jati diri bangsa Indonesia", ${ }^{18}$ yang harus dijaga, dilestarikan dan tetap dipertahankan dalam kehidupan bermasyarakat.

Adanya sifat fleksibel dalam pola pembagian hasil Mawah, karena norma-norma hukum dalam Hukum Adat dipengaruhi oleh berbagai faktor termasuk faktor norma hukum lain di luar Hukum Adat tersebut. Inilah yang oleh Werner Menski disebut dengan pluralisme hukum. Sehingga, apabila fleksibelitas pola pembagian hasil Mawah dikaitkan dengan pluralisme hukum yang terdapat dalam bukunya Werner Menski yang berjudul "Comparative Law in a Global Contex: (The Legal Systems of Asia and Africa)," Menski menguraikan pendapatnya tentang "legal pluralism (pluralisme hukum), yaitu suatu pendekatan dimana positive law (hukum positif/yang dalam hal ini adalah hukum negara), socio-legal approach (aspek pendekatan kemasyarakatan) dan religion, moral and ethic (agama, moral dan etika) merupakan suatu pertalian dan saling mempengaruhi". ${ }^{9}$

Menurut Menski, sebagaimana dikutip oleh I Putu Sastra Wibawa, 20 "pentingnya pluralisme hukum untuk memahami hukum dan tertib hukum, hukum dikaji tidak hanya mengkaji norma-norma saja, melainkan juga harus mempertimbangkan nilainilai, fakta, makna, proses, struktur, hubungan kekuasaan, personel, dan teknologi. Pluralisme hukum mengembangkan model hukum interaktif antara hukum negara, nilai-nilai/etika/agama dan norma-norma sosio-kultural."

Bertolak dari konsep pluralisme hukum tersebut, maka "pluralisme hukum dikonsepsikan sebagai cara pandang memahami hukum yang hidup dalam masyarakat

16 Wawancara dengan Narasumber Maulana, Masyarakat Sebagai Petani dan Penerima Mawah di Gampong (Kampung) Lam Leuot Kecamatan Kuta Cot Glie Kabupaten Aceh Besar, Sabtu, 27 Juni 2020.

17 Wawancara dengan Narasumber Basri, Masyarakat Sebagai Pemberi Mawah di Gampong (Kampung) Krueueng Blang Kecamatan Kuta Cot Glie Kabupaten Aceh Besar, Sabtu, 27 Juni 2020.

18 Walinews.com, Kesbangpol Aceh Gelar Sosialisasi Peningkatan Rasa Solidaritas dan Ikatan Sosial, https://wali-news.com/berita/kesbangpol-banda-aceh-gelar-sosialisasi-peningkatan-rasa-solidaritas-dan-ikatan-sosial/, diakses pada tanggal 10 Agustus 2020.

19 Werner Menski, Comparative Law in a Global Contex: (The Legal Systems of Asia and Africa), Cambridge University Press, United Kingdom, 2006, hlm. 187.

20 I Putu Sastra Wibawa, Hukum Tidak Tunggal: Potret Pluralisme Hukum Dalam Pengaturan Kawasan Tempat Suci Pura Uluwatu Di Bali. Jurnal DHARMA ASMRTI, vol.1 no.18 edisi Mei 2018, hlm. 49. 
yang dapat berdampingan dengan hukum yang diberlakukan oleh negara. Unsur terpenting yang menjadi karakteristik dalam pluralisme hukum adalah bekerjanya semua sistem hukum secara utuh. Unsur interaksi menjadi inheren dalam memahami konsep pluralisme, karena erat kaitannya dengan sistem hukum yang hidup dalam masyarakat majemuk, yang hidup dalam masyarakat didasarkan oleh sebuah kenyataan sosial masyarakat yang memiliki keragaman sistem hukum, sebagai wujud dari identitas sosial-budaya masyarakat. Keragaman identitas masyarakat dapat ditemukan dalam bentuk hukum adat, hukum agama, dan hukum negara". ${ }^{21}$

Demikian juga halnya dengan Mawah yang hidup dan berkembang dalam masyarakat Hukum Adat di Aceh, yang bersifat fleksibel sebagai salah satu bentuk solidaritas yang menjadi ikatan sosial di antara sesama warga masyarakat, juga dipengaruhi oleh norma-norma hukum yang lain termasuk agama, moral dan etika. Oleh karena itu, untuk menjaga rasa solidaritas dalam masyarakat, pembagian hasil Mawah dengan pola Bulueng Lhee tersebut masih bersifat fleksibel, tergantung dari sedikit atau banyaknya hasil panen yang diperoleh. Masyarakat merasa tidak adil dan tidak etis jika pembagian hasil Mawah tetap sebagaimana diperjanjikan, sementara hasil yang diperoleh Pemegang Mawah dari tanah tersebut sangatlah minim.

Berdasarkan uraian tersebut di atas dapat dipahami bahwa pola pembagian hasil dalam perjanjian Mawah di Kecamatan Kuta Cot Glie Kabupaten Aceh Besar dilakukan dengan pola Bulueng Lhee setelah dikurangi zakat, yaitu 1 bagian untuk pemberi Mawah dan 2 bagian untuk penerima Mawah. Walaupun demikian, untuk menjaga rasa solidaritas dalam masyarakat pembagian hasil dengan pola Bulueng Lhee tersebut masih bersifat fleksibel, tergantung dari sedikit atau banyaknya hasil panen yang diperoleh.

\section{Faktor Penyebab Mawah (Bagi Hasil Tanah Pertanian) Masih Eksis Dalam Ma- syarakat Kecamatan Kuta Cot Glie Kabupaten Aceh Besar}

\section{Sebagai sarana tolong menolong antar sesama warga masyarakat hukum adat}

Sebelumnya telah dijelaskan bahwa praktek Mawah tidak pernah hilang dalam kehidupan masyarakat hukum adat di Aceh, khususnya di Kecamatan Kuta Cot Glie Kabupaten Aceh Besar, karena Mawah merupakan sarana yang digunakan untuk saling tolong menolong antar sesama masyarakat hukum adat tersebut. Oleh karena itu praktek Mawah oleh masyarakat hukum adat di Kuta Cot Glie Kabupaten Aceh Besar merupakan salah satu pranata yang sangat penting keberadaannya dalam masyarakat dalam memenuhi kebutuhan hidup sehari-hari dan sebagai sarana tolong menolong.

21 Muhammadun dan Murjazin, Pluralisme Hukum Dalam Bingkai Masyarakat Madani. Jurnal Indo-Islamika, vol.4 no. 2 edisi Desember 2014, hlm.192-193. 
Mawah sebagai sarana tolong menolong, karena "yang paling penting adalah pembagian hasil itu sendiri sangat tergantung pada kesepakatan antara kedua belah pihak. Malahan, dalam beberapa kasus yang terjadi sistem Mawah diperuntukkan untuk membantu golongan ekonomi lemah oleh golongan ekonomi yang lebih mapan, sehingga bagi hasil-pun tidak terlalu dipentingkan". ${ }^{22}$

"Dengan bertambah pesatnya jumlah penduduk di Indonesia, sementara sifat tanah yang bersifat tetap dan luasnya tidak pernah bertambah, maka akan dapat menimbulkan suatu permasalahan sendiri bagi masyarakat dalam memenuhi kebutuhannya seharihari". 23 "Tanah adalah suatu yang mempunyai mutu yang begitu penting dalam kehidupan manusia, sebab tanah sama besar dengan keberlangsungan kehidupan manusia, dimana semua kebutuhan manusia untuk bertahan hidup bersumber dari tanah". ${ }^{24}$

Keberadaan lembaga Mawah yang berlangsung dalam kehidupan masyarakat hukum adat sangat erat kaitannya dengan semangat tolong menolong dan menghindarkan diri dari kesulitan akan kebutuhan hidup sehari-hari. Hal ini terjadi karena "adanya anggota masyarakat yang tidak memiliki tanah garapan, sementara di sisi lain ada yang memiliki tanah dengan jumlah yang luas atau memiliki beberapa bidang tanah, maka pemilik tanah tersebut menyerahkan tanahnya itu kepada orang lain yang sama sekali tidak mempunyai tanah untuk digarap. Penyerahan itu dilakukan secara Mawah atau memawah-kan (Peumawah) dengan perjanjian bahwa hasilnya nanti akan dibagi antara pemberi Mawah dengan penerima Mawah, yang menurut kebiasaan yang berlaku dalam masyarakat sebesar 1: 3 (1 bagian untuk pemberi Mawah dan 2 bagian untuk penerima Mawah setelah dikeluarkan zakatnya jika mencapai Nisab)".25

"Mawah di Aceh merupakan model economy sharing antara pemilik tanah dan para pengelola (penggarap) dalam kegiatan ekonomi. Sebagai muslim yang taat dan kental dengan tradisi Islam, masyarakat Aceh sudah terbiasa mempraktikkan nilai-nilai Islam termasuk dalam bidang perekonomian. Salah satu bagian dari sistem ekonomi Islam adalah Mawah, namun Mawah hanya berlaku secara informal dan pada ruang lingkup privat (pribadi), belum diterapkan secara formal dan berlaku umum". ${ }^{26}$ Oleh karena itu, Majelis Permusyawaratan Ulama (MPU) Aceh melaksanakan Kegiatan Sidang Paripurna - IV pada tanggal 25 s.d. 27 Juli 2016, dengan tema yang diangkat adalah

22 Azharsyah Ibrahim, (2012), Praktik Ekonomi Masyarakat Aceh Dalam Konteks Ekonomi Islam: Kajian Terhadap Sistem Mawah dan Gala, Proceeding of The Aceh Development International Conference 2012, Kuala Lumpur, Malaysia, March 26-28.

23 Elsa Indira Larasati dan Lavenia Nadya Irianti, Konflik Surat Ijo Dalam Penerbitan Izin Pemakaian Tanah Hak Pengelolaan Di Kota Surabaya. Syiah Kuala Law Journal, vol.4 no.2 edisi Agustus 2020, hlm. 186.

24 I Made Krishna Dharma Kusuma, Putu Gede Seputra dan Luh Putu Suryani, Peralihan Hak Atas Tanah Melalui Jual Beli Berdasarkan Hukum Adat. Jurnal Interpretasi Hukum, vol.1 no.2 edisi September 2020, hlm. 213-214.

25 Wawancara dengan Narasumber Taufiq AR., Masyarakat Sebagai Pemilik dan Pemberi Mawah di Kampung (Gampong) Bak Sukon, Kecamatan Kuta Cot Glie Kabupaten Aceh Besar, Senin, 29 Juni 2020.

26 Hamdani, Praktik Mawah Sebagai Model Economy Sharing Memberantas Kemiskinan, https://acehsatu.com/praktik-mawah-sebagai-model-economy-sharing-memberantas-kemiskinan/, diakses pada tanggal 08 Agustus 2020. 
"Dengan Mawah Kita Tingkatkan Perekonomian Syariah Masyarakat Aceh". Adapun yang menjadi narasumbernya adalah :

1. "Prof. Dr. Tgk. H. Muslim Ibrahim, MA. (Ketua MPU Aceh) dengan judul Mawah Di Aceh Dalam Perspektif Fiqh Islam;

2. Tgk. H. Faisal Ali (Wakil Ketua MPU Aceh) dengan judul Praktek Mawah Dalam Masyarakat Aceh; dan

3. Syamsuddin Daud, SH., MH. (Wakil Ketua Majelis Adat Aceh) denganjudul Mawah dalam Kajian Hukum Ekonomi". ${ }^{27}$

Hari terakhir dari pertemuan tersebut tanggal 27 Juli 2016 MPU mengeluarkan fatwa yaitu Fatwa MPU Aceh No. 4 Tahun 2016 tentang Mawah. Dengan pertimbangan yang tercantum dalam konsiderannya antara lain : "bahwa dalam masyarakat Aceh telah berkembang secara turun temurun tradisi Mawah sebagai salah satu bentuk mu'amalat, sehingga praktek Mawah perlu dilakukan kajian figh secara mendalam. Di samping itu juga MPU Aceh meminta kepada Pemerintah Aceh membuat Qanun Sistem Mawah yang sesuai syariat Islam, karena Mawah sudah menjadi tradisi atau adat di dalam masyarakat Aceh. Para pihak yang terlibat dalam akad Mawah juga diminta membuat perjanjian secara tertulis". ${ }^{28}$

Jadi, praktek Mawah di Aceh berbeda dengan perjanjian bagi hasil di beberapa daerah lainnya di Indonesia, yang dikhawatirkan atau "sering merugikan penggarap karena tanah yang tersedia terbatas. Sementara di lain sisi jumlah penggarap cukup banyak, sehingga tidak jarang penggarap harus menerima syarat-syarat yang ditetapkan pemilik tanah". 29

Dengan demikian karena Mawah dapat menjadi sarana tolong menolong dalam memenuhi kebutuhan sebagian warga masyarakat dan termasuk salah satu bentuk mu'amalat yang sangat bermanfaat bagi masyarakat, maka Mawah tetap eksis hingga saat sekarang ini, bahkan MPU Aceh telah mengeluarkan fatwanya tentang Mawah dan meminta Pemerintah Aceh mengaturnya dalam bentuk Qanun.

\section{Sebagai salah satu cara memproduktifkan tanah}

Tanah dalam kehidupan manusia mempunyai "peranan yang sangat penting karena tanah merupakan salah satu sumber daya alam yang bisa dimanfaatkan sebagai instrument pemenuhan kebutuhan dan perwujudan kesejahteraan rakyat. Semua manusia membutuhkan tanah, baik untuk tempat tinggal maupun untuk

27 Serambinews.com, MPU: Qanunkan Sistem Mawah Sesuai Syariah, https://aceh.tribunnews.com/2016/07/28/ mpu-qanunkan-sistem-mawah-sesuai-syariat, diakses pada tanggal 11 Agustus 2020.

28 Ibid.

29 Rahmat Ramadhani, (2019), Dasar-dasar Hukum Agraria, Pustaka Prima, Medan, hlm. 174-175. 
keperluan lainnya, sehingga tanah merupakan sumber kehidupan, kesejahteraan dan kemakmuran". 30

Tanah merupakan sumber kehidupan manusia, dimana "tanah mempunyai fungsi ganda, yaitu sebagai social asset dan capital asset. Fungsi tanah sebagai social asset maksudnya tanah merupakan sarana pengikat kesatuan di antara sesama anggota masyarakat. Sementara itu tanah sebagai capital asset merupakan faktor modal dalam pembangunan" 31 dan "tanah harus dipergunakan serta dimanfaatkan sebesar-besarnya untuk kesejahteraan rakyat secara adil dan merata, juga harus dijaga kelestariannya". 32

Mengingat tanah sebagai faktor modal, maka pemilik tanah akan berusaha supaya tanah yang dimilikinya dapat dimanfaatkan secara produktif, sehingga tanahnya tidak terbengkalai dan menjadi lahan tidur. Apalagi "bagi orang-orang yang mempunyai beberapa bidang tanah, karena tidak sanggup menggarap sendiri akhirnya diserahkan kepada orang lain untuk menggarapnya. Penyerahan ini dalam masyarakat Aceh pada umumnya dan masyarakat Kecamatan Kuta Cot Glie Kabupaten Aceh Besar khususnya dilakukan dengan sistem Mawah. Dengan perjanjian bahwa tanah tersebut diusahakan (digarap) oleh penerima Mawah dan hasilnya akan dibagi antara pemberi Mawah dengan penerima Mawah sesuai kebiasaan dalam masyarakat", ${ }^{33}$ yaitu sebesar $1: 3$ sebagaimana telah dikemukakan di atas.

Berdasarkan uraian di atas dapat dipahami bahwa seseorang yang memiliki beberapa bidang tanah dan tidak mungkin dapat mengolahnya sendiri, maka supaya tanah tersebut tetap berproduksi diserahkanlah kepada pihak lain untuk mengusahakan atau menggarapnya melalui sistem Mawah. "Apabila tanah itu tidak diusahakan, sementara tanah tersebut merupakan lahan produktif, maka perbuatan membiarkan tanahnya tidak diusahakan termasuk dalam perbuatan mubazir yang dalam hal ini adalah menyia-nyiakan harta". ${ }^{34}$ Demikian juga halnya dengan "penelantaran tanah selain merupakan tindakan yang tidak bijaksana, tidak ekonomis (hilangnaya peluang untuk mewujudkan potensi ekonomi tanah), dan tidak berkeadilan, serta juga merupakan suatu pelanggaran terhadap kewajiban yang harus dijalankan para pemegang hak atau pihak yang telah memperoleh dasar penguasaan tanah. Penelantaran tanah juga berdampak pada terhambatnya pencapaian berbagai tujuan program pembangunan, rentannya

30 Abdurrahman, Tanah Untuk Masyarakat Golongan Ekonomi Lemah. KANUN Jurnal Ilmu Hukum, vol.14 no.1 edisi April 2012, hlm. 139.

31 Docplayer.info, https://docplayer.info/98257366-Bab-i-pendahuluan-ganda-yaitu-tanah-sebagai-social-asset-dantanah-sebagai-capital-asset.html, diakses pada tanggal 29 Agustus 2020.

32 Komang Agus Sujana, Ketut Sudiatmaka dan Ni Ketut Sari Adnyani, Efektifitas Pelaksanaan Undang Undang Nomor 2 Tahun 1960 Tentang Perjanjian Bagi Hasil Terhadap Tanah Pertanian Di Desa Umejero Kecamatan Busungbiu Kabupaten Buleleng. Jurnal Komunitas Yustisia, vol.3 no.2 edisi Agustus 2020, hlm.115.

33 Wawancara dengan Narasumber Sofyan, Masyarakat Sebagai Pemilik dan Pemberi Mawah di Kampung (Gampong) Bak Sukon, Kecamatan Kuta Cot Glie Kabupaten Aceh Besar, Senin, 06 Juli 2020.

34 Serambinews.com, Mubazir Dalam Perspektif Al-Quran, https://aceh.tribunnews.com/2013/11/01/mubazir-dalam-perspektif-alquran, diakses pada tanggal 29 Agustus 2020. 
ketahanan pangan dan ketahanan ekonomi nasional, tertutupnya akses sosial ekonomi masyarakat khususnya petani pada tanah serta terusiknya rasa keadilan". ${ }^{35}$ Oleh karena itu tepatlah kiranya jika pemilik tanah terus berusaha supaya tanahnya tetap produktif, walaupun melalui sistem Mawah, sehingga tanahnya tidak terbengkalai melainkan tetap menghasilkan.

\section{Adanya penguasaan tanah dengan cara gadai}

Pada umumnya perjanjian menyerahkan tanah kepada pihak lain untuk diusahakan supaya tanah tersebut tetap berproduksi melalui sistem Mawah, dilakukan oleh pemilik tanah yang mempunyai beberapa bidang tanah. Namun, "adakalanya Mawah terjadi ketika seseorang menguasai suatu bidang tanah karena yang bersangkutan menerima gadai tanah (menjadi pemegang gadai). Pemegang gadai tersebut pekerjaannya seharihari bukanlah petani, akan tetapi karena ada orang yang menggadaikan tanah padanya, maka yang bersangkutan menguasai tanah pertanian (sawah) sebagai penerima gadai. Supaya tanah tersebut tetap diusahakan, diserahkanlah kepada orang lain untuk menggarapnya. Biasanya yang menjadi penggarap (penerima Mawah) di sini adalah pemilik asli (pemberi gadai) dari tanah tersebut". ${ }^{36}$

Sama halnya dengan Mawah, "Gadai tanah juga dilaksanakan menurut hukum adat, karena gadai merupakan salah satu lembaga yang dikenal dan dilaksanakan menurut hukum adat atau menurut kebiasaan dalam masyarakat setempat". ${ }^{37}$ Dalam hal ini "gadai tanah adalah penyerahan sebidang tanah milik seseorang kepada orang lain untuk sementara waktu, dengan pembayaran sejumlah uang oleh pihak lain secara tunai sebagai uang gadai. Pemilik tanah baru memperoleh tanahnya kembali apabila melakukan penebusan dengan sejumlah uang yang sama". 38

Hal yang sama juga dikemukakan oleh Marsyuddin yang bahwa "gadai tanah merupakan suatu perjanjian yang menyebabkan tanahnya diserahkan untuk menerima tunai sejumlah uang, dengan permufakatan bahwa si penyerah (penggadai atau pemberi gadai) akan berhak mengembalikan tanah itu ke dirinya sendiri dengan jalan menebusnya dengan cara membayarkan sejumlah uang yang sama sejumlah yang diterima penggadai".39

35 Monica Julina Jaya, Tindakan Kepala Desa Menjadikan Tanah Terlantar Sebagai Tanah Gogol Ditinjau Dari Undang-Undang No. 5 Tahun 1960 Tentang Peraturan Dasar Pokok-pokok Agraria. Calyptra: Jurnal Ilmiah Mahasiswa Universitas Surabaya, vol.2 no.1 edisi Agustus 2013, hlm. 2.

36 Wawancara dengan Narasumber Subhan, Masyarakat Sebagai Pedagang (penerima gadai dan pemberi Mawah) di Kampung (Gampong) Keumireu, Kecamatan Kuta Cot Glie Kabupaten Aceh Besar, Senin, 6 Juli 2020.

37 Nur Ridwan Ari Sasongko, Gadai Tanah/Sawah Menurut Hukum Adat Dari Masa Ke Masa. Jurnal Repertorium, vol.1 no.2 edisi November 2014, hlm. 23.

38 Urip Santoso, (2012), Hukum Agraria Kajian Komprehensif, Cet. I, Kencana, Jakarta. hlm. 135.

39 Marsyuddin, Eksistensi Perjanjian Gala (Gadai) Tanah Pertanian Pada Masyarakat Aceh Di Kecamatan Meurah Mulia Kabupaten Aceh Utara. Premise Law Jurnal, vol.1 no.2 edisi Desember 2013, hlm. 2. 
Dengan demikian dapat dipahami bahwa dalam hal seseorang menjadi pemegang gadai atau menguasai tanah pertanian (sawah) melalui perjanjian gadai, sementara yang bersangkutan bukanlah berprofesi sebagai petani, maka supaya tanah tersebut tetap menghasilkan diserahkanlah tanah tersebut kepada orang lain untuk menggarapnya dengan sistem Mawah. Hal ini juga menjadi salah satu faktor penyebab Mawah masih tetap berlangsung dan dipertahankan dalam masyarakat Kecamatan Kuta Cot Glie Kabupaten Aceh Besar.

\section{SIMPULAN}

Pola pembagian hasil dalam perjanjian bagi hasil tanah pertanian (Mawah) di Kecamatan Kuta Cot Glie Kabupaten Aceh Besar dilakukan dengan pola Bulueng Lhee (bagi tiga) dengan perbandingan 1 : 3 setelah dikurangi zakat, yaitu 1 bagian untuk pemberi Mawah dan 2 bagian untuk penerima Mawah selaku penggarap tanah. Adapun faktor penyebab Mawah masih eksis dalam masyarakat karena sebagai sarana tolong menolong antar sesama warga masyarakat. Kemudian karena pemilik tanah tidak sanggup mengolah sendiri tanahnya, maka sebagai salah satu cara memproduktifkan tanah dibuatlah perjanjian Mawah dengan pihak lain selaku penerima Mawah. Seseorang yang menguasai tanah secara gadai (penerima gadai) juga merupakan salah satu faktor penyebab terjadinya Mawah, karena pekerjaan sehari-hari penerima gadai bukanlah petani sehingga tidak terbiasa mengolah atau menggarap tanah.

\section{DAFTAR PUSTAKA}

\section{Buku}

Rahmat Ramadhani, (2019), Dasar-dasar Hukum Agraria, Pustaka Prima, Medan.

Urip Santoso, (2012), Hukum Agraria Kajian Komprehensif, Cet. I, Kencana, Jakarta.

Werner Menski, (2006), Comparative Law in a Global Contex: (The Legal Systems of Asia and Africa), Cambridge University Press, United Kingdom.

\section{Jurnal}

Abdurrahman, (2012), Tanah Untuk Masyarakat Golongan Ekonomi Lemah, (2012), KANUN Jurnal Ilmu Hukum, Vol. 14 No. 1, Edisi April, hlm. 139-147.

Elsa Indira Larasati dan Lavenia Nadya Irianti, (2020), Konflik Surat Ijo Dalam Penerbitan Izin Pemakaian Tanah Hak Pengelolaan Di Kota Surabaya, Syiah Kuala Law Journal, Vol. 4 No.2, Edisi Agustus, hlm. 185-197.

Furqan dan Elva Hidayan S., (2018), Pemberdayaan Masyarakat Melalui Tradisi Mawah (Studi Kasus Pemeliharaan Ternak Sapi di Desa Mibo Kecamatan Banda Raya Banda Aceh), AL-IDARAH: Jurnal Manajemen dan Administrasi Islam, Vol. 2 No. 1, Edisi Juni, hlm. 25-37. 
Hasan Basri, (2011), Kedudukan Syariat Islam di Aceh dalam Sistem Hukum Indonesia, KANUN Jurnal Ilmu Hukum, Vol. 13 No. 3, Edisi Desember, hlm. 75-92.

Komang Agus Sujana, Ketut Sudiatmaka dan Ni Ketut Sari Adnyani, (2020), Efektifitas Pelaksanaan Undang Undang Nomor 2 Tahun 1960 Tentang Perjanjian Bagi Hasil Terhadap Tanah Pertanian Di Desa Umejero Kecamatan Busungbiu Kabupaten Buleleng, Jurnal Komunitas Yustisia, Vol. 3 No. 2, Edisi Agustus, hlm. 114-123.

Made Krishna Dharma Kusuma, I., Putu Gede Seputra dan Luh Putu Suryani, (2020), Peralihan Hak Atas Tanah Melalui Jual Beli Berdasarkan Hukum Adat, Jurnal Interpretasi Hukum, Vol. 1 No. 2, Edisi September, hlm. 213-217.

Marsyuddin, (2013), Eksistensi Perjanjian Gala (Gadai) Tanah Pertanian Pada Masyarakat Aceh Di Kecamatan Meurah Mulia Kabupaten Aceh Utara, Premise Law Jurnal, Vol. 1 No. 2, Edisi Desember, hlm. 1-15.

Monica Julina Jaya, (2013), Tindakan Kepala Desa Menjadikan Tanah Terlantar Sebagai Tanah Gogol Ditinjau Dari Undang-Undang No. 5 Tahun 1960 Tentang Peraturan Dasar Pokok-pokok Agraria, Calyptra: Jurnal Ilmiah Mahasiswa Universitas Surabaya, Vol. 2 No. 1, Edisi Agustus, hlm. 1-13.

Muhammad Arifin dan Khadijah Binti Mohd Khambali, (2016), Islam dan Akulturasi Budaya Lokal di Aceh (Studi Terhadap Ritual Rah Ulei di Kuburan Dalam Masyarakat Pidie Aceh), Jurnal Ilmiah ISLAM FUTURA, Vol. 15 No. 2, Edisi Februari, hlm. 251-284.

Muhammadun dan Murjazin, (2014), Pluralisme Hukum Dalam Bingkai Masyarakat Madani, Jurnal Indo-Islamika, Vol. 4 No. 2, Edisi Desember, hlm.190-201.

Mukhtasar dan Angga Syahputra, (2020), Optimizing The Mawah Concept for The Economy of The Aceh Community, IQTISHODUNA: Jurnal Ekonomi Islam, Vol. 9 No. 2, Edisi Oktober, hlm. 167-180.

Nur Ridwan Ari Sasongko, (2014), Gadai Tanah/Sawah Menurut Hukum Adat Dari Masa Ke Masa, Jurnal Repertorium, Vol. 1, No. 2 Edisi November, hlm. 18-23.

Purwaning Rahayu Sisworini, Abdul Majid dan Herman Suryokumoro, (2020), Penerapan Honorarium PPAT Sebagai Upaya Untuk Penyetaraan Pelayanan (Studi Kasus Di Kota Malang), Jurnal IUS Kajian Hukum dan Keadilan, Vol. 8 No. 3, Edisi Desember, hlm. 512-528.

Putu Sastra Wibawa, I., (2018), Hukum Tidak Tunggal: Potret Pluralisme Hukum Dalam Pengaturan Kawasan Tempat Suci Pura Uluwatu Di Bali, Jurnal DHARMA ASMRTI, Vol. 1 No. 18, Edisi Mei, hlm. 45-53.

Syamsuddin, (2018), Peran Konsep "Mawah" Sebagai Edukasi Permodalan Masyarakat Aceh, Jurnal NEGOTIUM, Vol. 1 No. 1, Edisi April, hlm. 41-45.

\section{Prosiding}

Azharsyah Ibrahim, (2012), Praktik Ekonomi Masyarakat Aceh Dalam Konteks Ekonomi Islam: Kajian Terhadap Sistem Mawah dan Gala, Proceeding of The Aceh Development International Conference 2012, Kuala Lumpur, Malaysia, March 26-28. 


\section{Peraturan Perundang-Undangan}

Undang-Undang Republik Indonesia No. 2 Tahun 1960 Tentang Perjanjian Bagi Hasil (Lembaran Negara No. 98 Tahun 1960).

Undang-Undang Republik Indonesia No. 5 Tahun 1960 Tentang Peraturan Dasar Pokok-Pokok Agraria (Lembaran Negara No. 104 Tahun 1960).

\section{Website}

Azhari, https://aceh.kemenag.go.id/berita/510267/azhari-tingkatkan-kepeduliansosial-untuk-membantu-sesama-di-tengah-wabah, diakses pada tanggal 02 Agustus 2020.

Badan Amil Zakat Nasional, Provinsi Kepulauan Bangka Belitung, Zakat Pertanian, https:// baznasbabel.com/zakat-pertanian/, diakses pada tanggal 08 Agustus 2020.

Docplayer.info, https://docplayer.info/98257366-Bab-i-pendahuluan-ganda-yaitu-tanahsebagai-social-asset-dan-tanah-sebagai-capital-asset.html, diakses pada tanggal 29 Agustus 2020.

Dompet Dhuafa, Cara Menentukan Zakat Hasil Pertanian, Buah-buahan, Bunga dan Sayuran, https://zakat.or.id/cara-menentukan-zakat-hasil-pertanian/, diakses pada tanggal 08 Agustus 2020.

Hamdani, Praktik Mawah Sebagai Model Economy Sharing Memberantas Kemiskinan, https:// acehsatu.com/praktik-mawah-sebagai-model-economy-sharing-memberantaskemiskinan/, diakses pada tanggal 08 Agustus 2020.

Serambinews.com, MPU: Qanunkan Sistem Mawah Sesuai Syariah, https://aceh.tribunnews. com /2016/07/28/mpu-qanunkan-sistem-mawah-sesuai-syariat, diakses pada tanggal 11 Agustus 2020.

, Mubazir Dalam Perspektif Al-Quran, https://aceh.tribunnews.com/2013/11/01/ mubazir-dalam-perspektif-alquran, diakses pada tanggal 29 Agustus 2020.

Walinews.com, Kesbangpol Aceh Gelar Sosialisasi Peningkatan Rasa Solidaritas dan Ikatan Sosial, https://wali-news.com/berita/kesbangpol-banda-aceh-gelarsosialisasi-peningkatan-rasa-solidaritas-dan-ikatan-sosial/, diakses pada tanggal 10 Agustus 2020. 